\title{
ОЦІНЮВАННЯ ПОТРЕБИ У ФАХІВЦЯХ В ОХОРОНІ ЗДОРОВ'Я ТА ЇХ ПІДГОТОВКИ В СИСТЕМІ ПІСЛЯДИПЛОМНОї ОСВІТИ (Друге повідомлення)
}

\author{
Ю. В. Вороненко, О. П. Мінцер \\ Національна медична академія післядипломної освіти імені П. Л. Шупика
}

\begin{abstract}
На основі нової моделі оцінювання кадрових ресурсів охорони здоров'я розглянуто можливості їх прогнозування та обґрунтування стратегії підготовки відповідних спеціалістів. Обговорено методологічні особливості розрахунків щодо підготовки кадрів. Означені розрахунки розглянуто з позицій потреб населення в медичних послугах і попиту на них. Запропоновано нову градієнтно-переривчасто-ступеневу систему підготовки фахівців у післядипломній медичній освіті, що представляє систему підготовки спеціалістів, при якій навчальний контент і функціональні обов'язки фахівців конгруентні.
\end{abstract}

Ключові слова: кадрові ресурси охорони здоров'я, інформаційні технології, методи розрахунку потреби в кадрах, система охорони здоров'я, якість надання медичних послуг, градієнтно-переривчасто-ступенева модель формування КРОЗ, індикатори та орієнтири.

\section{ОЦЕНКА ПОТРЕБНОСТИ В СПЕЦИАЛИСТАХ В ЗДРАВООХРАНЕНИИ И ИХ ПОДГОТОВКИ В СИСТЕМЕ ПОСЛЕДИПЛОМНОГО ОБУЧЕНИЯ} (Второе сообщение)

\author{
Ю. В. Вороненко, О. П. Минцер \\ Национальная медицинская академия последипломного образования \\ имени П. Л. Шупика
}

\begin{abstract}
На основе новой модели оценки кадровых ресурсов здравоохранения рассмотрены возможности их прогнозирования и обоснования стратегии подготовки соответствующих специалистов. Обсуждены методологические особенности расчетов по подготовке кадров. Эти расчеты рассмотрены с позиций потребностей населения в медицинских услугах и спроса на них. Предложена новая градиентно-прерывисто-ступенчатая система подготовки кадров в последипломном медицинском образовании, представляющая такую систему подготовки специалистов, при которой образовательный контент и функциональные обязанности специалистов конгруэнтны.
\end{abstract}

Ключевые слова: кадровые ресурсы здравоохранения, информационные технологии, методы расчета потребности в кадрах, система здравоохранения, качество оказания медицинских услуг, градиентно-прерывисто-ступенчатая система подготовки кадров, индикаторы и ориентиры.

\section{ASSESSMENT OF THE NEED FOR SPECIALISTS IN HEALTH CARE AND THEIR TRAINING IN THE POSTGRADUATE EDUCATION SYSTEM}

\section{(Second post)}

\author{
Yu. V. Voronenko, O. P. M intser \\ National Medical Academy of Postgraduate Education by P. L. Shupyk
}

\begin{abstract}
It's proposed the basis of a new model of assessment of the human resources for health (HRH). There's considered the possibility of their prediction and study strategies related skills. It's discussed methodological features calculation training. These calculations are considered from the standpoints of needs perspective of the population in the health services and the demand for them. There's proposed a new gradient-ntermittent-step system for postgraduate medical training, in which educational content and responsibilities of specialists are congruent.
\end{abstract}

Key words: human resources for health, information technology, methods of calculating staffing requirements, the health system, the quality of medical services, gradient-inter mittent-step training system, indicators and benchmarks.

(C) Ю. В. Вороненко, О. П. Мінцер 
Від авторів. У даній роботі продовжено висвітлення розробленої нами методології розрахунку кадрових ресурсів охорони здоров'я (КРОЗ), що базується на адаптованих для України керівництвах, моделях та оцінках планування КРОЗ Всесвітньої організації охорони здоров'я (ВОО3). Дискутується можливість застосування методики в практичній охороні здоров'я України та в системі підготовки фахівців в післядипломній медичній освіті на основі градієнтно-переривчасто-ступеневої моделі.

Вступ. У попередньому повідомленні підкреслено, що запобігання та корекція ризиків виникнення кадрового дисбалансу (дефіциту, надлишку, нераціонального розподілу кадрів) є тепер найактуальнішою проблемою планування кадрових потреб. У цьому повідомленні представлено можливість застосування класичних і нових концептуальних положень, а також окремі сучасні методичні підходи планування кадрових ресурсів охорони здоров'я.

Методичні підходи. Класичні підходи до планування КРОЗ пов'язані з використанням стратегії управління, що, в свою чергу, базується на системі критеріїв та індикаторів. Підкреслимо, що для кожного 3 важелів управління охороною здоров'я має бути свій критерій і набір кількісних індикаторів, які використовувалися в попередніх дослідженнях або оцінках, задокументовані в літературі або розроблені для цього інструменту на теоретичній основі.

Вочевидь, скрізь, де можливі кількісні індикатори, вони супроводжуються цільовими орієнтирами. Проте існує безліч індикаторів, для яких немає ні наукових, ні експериментальних даних, що дозволяють надати прийнятний орієнтир. Оскільки не очікується, що кожен із індикаторів буде застосований або корисний у всіх контекстах, для вибору найадекватніших із пропонованих і цільових орієнтирів у конкретних випадках необхідне знання стану справ у демографічних процесах та в діяльності системи охорони здоров 'я в країні. Деякі з потрібних знань можна отримати 3 інтерв'ю 3 ключовими фахівцями - досвідченими місцевими посадовими особами, які займаються питаннями кадрових ресурсів охорони здоров'я, а також із експертами з фінансування, управління та освіти в галузі охорони здоров'я. В інших випадках для отримання інформації необхідне проведення оперативних обстежень, використання фокусних груп або взаємодія з національними та регіональними експертами. Отже, можна виділити стратегічні та оперативні питання підготовки КРОЗ, а здійснювати оцінювання КРОЗ рекомендуємо згідно з рішеннями BOO3.
Як відомо, ВООЗ рекомендує етапну процедуру оцінювання кадрових ресурсів [4]. У кожному з компонентів процедури для проведення оцінювання різних елементів, що відносяться до кадрових ресурсів охорони здоров'я, пропонується меню діагностичних індикаторів. Ці індикатори відбираються, в свою чергу, на основі трьох критеріїв: теоретичний або емпіричний зв'язок із кадровими ресурсами охорони здоров'я; адаптованість індикаторів із попередніх інструментів стосовно людських ресурсів і реальні умови для збору даних. Очевидно, що доцільність або здійсненність збору даних за різними індикаторами буде в конкретному випадку відрізнятися. 3 урахуванням цього факту інтерес представляють лише основні індикатори, що є найактуальнішими, їх доступність найімовірніша або приблизне оцінювання яких можна провести з найбільшою ймовірністю. Природно, можливі й інші індикатори (додаткові) на додаток до основних або ключових індикаторів.

Навіть теоретично статичні індикатори можуть дати помилкове уявлення щодо потрібних КРОЗ. Тим більше, що важливим фактором впливу може виступати неадекватність системи медичної освіти, а саме: недостатній рівень компетентності медичного персоналу, невідповідність підготовки фахівців рівню розвитку охорони здоров'я і структурі системи тощо. Недостатня мотивація суб'єктів навчання може бути обумовлена неадекватною заробітною платою. Останній фактор, окрім прямого впливу на кадрові ресурси охорони здоров'я, може впливати опосередковано шляхом зниження привабливості окремих професій у порівнянні з різними видами діяльності в інших секторах і призвести до нестачі кадрів для роботи в системі охорони здоров'я. В результаті можливе зниження якості медичної допомоги чи рівня послуг, що, в кінцевому рахунку, негативно позначиться на стані здоров'я населення.

Все це при першому ознайомленні з вирішенням проблеми оптимізації КРОЗ створює враження про неможливість коректного та наукового обгрунтування вирішення проблеми обсягів КРОЗ навіть у регіональному масштабі, тим більше в масштабах країни.

Проте автори вважають, що створення стратегії формування КРОЗ не тільки можливе, але й доцільне. Розглянемо зміст пропозиції.

Результати та їх обговорення. При розробленні стратегічного плану використовували основні індикатори, а для проведення точнішого оцінювання зокрема, управління якістю - додаткові. Якщо дані по основних індикаторах були недоступні, оцінювання проводилось на основі експертних висновків. 
Кінцевою метою була тріангуляція отриманих даних відповідно до специфічних умов роботи. Кожен раз, коли це необхідно, та в тій мірі, в якій можливо, для забезпечення найкращого оцінювання ситуації 3 КРОЗ у розглянутому регіоні, індикатори, запропоновані в цьому інструментарії, можуть бути замінені на альтернативні.

Пропонується визначати КРОЗ на підставі трендових та оперативних показників якості надання медичної допомоги. Подібна пропозиція детально в літературі не обговорювалася. Досвіду іiі застосування практично немає. Тому сподіватися на швидке та адекватне вирішення проблем підготовки КРОЗ не варто.

Якщо як індикатор КРОЗ розглядати критерії якісного надання медичної допомоги, то не слід забувати, що вони є відображенням функціонування складної системи організації охорони здоров'я з багатоетапною процедурою оцінювання стану здоров'я та надання необхідної корекційної або радикальнішої допомоги. При розгляді питання про недостатньо кваліфіковану допомогу хворим вузькоспеціалізованого напряму (наприклад, в отоларингології) розуміли, що до появи ознак захворювання істотну роль у зміцненні здоров 'я повинні були зіграти лікарі первинної ланки (первинної медико-санітарної допомоги), кваліфікованої медичної допомоги (лікарі другої лан- ки) та численні інші фактори, що впливають на ефективність процесу надання медичної допомоги. Їх кількість можна продовжити: це й індивідуальні особливості та особливості поведінки індивіда щодо забезпечення здорового способу життя, й супутні захворювання (або фактори ризику), інфекційні фактори тощо. Важливо враховувати й матеріальні ресурси забезпечення здоров'я - наявність лікарських засобів і виробів медичного призначення, необхідної апаратури та технологій, а також адміністративних ресурсів (фінансування, засобів доставки медичних послуг тощо).

Як вже згадувалося, методологія ВОО3 базується на використанні двох кількісних критеріїв - індикатори та орієнтири. Кожен із них, у свою чергу, пов'язаний із посиланнями та обговоренням.

Виділимо два завдання: 1. Визначення модельних (статистично обгрунтованих) потреб у КРОЗ і відповідну їм потребу підготовки відповідних спеціалістів. 2. Оперативна стратегія (в певному сенсі випливає 3 модельних потреб) вирішення проблеми КРОЗ.

У стратегічному плануванні більшість країн орієнтується на опорні критерії (табл. 1), причому розробка державної моделі повинна забезпечити розуміння того, як кожен із соціальних важелів може впливати на різні фактори, важливі для діяльності систем охорони здоров'я.

Таблиця 1. Інструмент стратегічного планування: концептуальна структура для оцінки кадрових ресурсів охорони здоров'я

\begin{tabular}{|c|c|c|c|c|}
\hline Соціальні важелі & $\begin{array}{l}\text { Наскрізні } \\
\text { соціальні } \\
\text { проблеми } \\
\end{array}$ & Стан КРОЗ & $\begin{array}{c}\text { Цілі системи } \\
\text { охорони здоров'я }\end{array}$ & $\begin{array}{c}\text { Цілі } \\
\text { у відношенні } \\
\text { здоров'я } \\
\end{array}$ \\
\hline Фінансування & $\begin{array}{l}\text { Привабливість } \\
\text { професії }\end{array}$ & $\begin{array}{l}\text { Рівень щільності КРОЗ: } \\
\text { - категорія КРОЗ }\end{array}$ & $\begin{array}{l}\text { Забезпечення якості } \\
\text { надання медичної } \\
\text { допомоги }\end{array}$ & $\begin{array}{l}\text { Стан здоров'я } \\
\text { населення }\end{array}$ \\
\hline Освіта & Міграція & $\begin{array}{l}\text { Розподіл КРОЗ: } \\
\text { - професійна структура } \\
\text { всередині категорії; } \\
\text { - географічна локалізація }\end{array}$ & Ефективність & $\begin{array}{l}\text { Достатність } \\
\text { фінансування }\end{array}$ \\
\hline $\begin{array}{l}\text { Оптимізація } \\
\text { управління }\end{array}$ & Мотивація & $\begin{array}{l}\text { Діяльність КРОЗ: } \\
\text { - якість роботи (ефективність } \\
\text { охорони здоров'я) }\end{array}$ & $\begin{array}{l}\text { Справедливість / } \\
\text { доступність, } \\
\text { стійкість }\end{array}$ & Чуйність \\
\hline
\end{tabular}

Показники діяльності кадрових ресурсів охорони здоров'я складаються з ефективності роботи персоналу й обсягу та якості надаваних послуг. Ефективність роботи фахівців охорони здоров'я може бути проаналізована з позицій фінансових розрахунків (наприклад, число зайнятих працівників охорони здоров'я на витрачені кошти) та продуктивності (наприклад, число наданих послуг на людино-годину) [2]. Обидві оцінки мають велике значення для діяльності систем охорони здоров'я з точки зору оптимального використання обмежених ресурсів і стримування витрат на медичних працівників. Проте, прості сукупні індикатори можуть маскувати вплив інших виробничих факторів (матеріалів, обладнання), а також взаємозв'язок між кількісними й якісними результатами.

Загальна мета полягає в досягненні більш справедливого географічного розподілу КРОЗ, хоча лише деякі розвинені країни здатні досягти цього цільово- 
го орієнтиру. Зрозуміло, що можливе використання низки соціальних заходів із подолання такого дисбалансу за допомогою стимулів і нормативних положень, проте, їх використання може дати лише незначний ефект.

Зазначений підхід дає лише дуже приблизне уявлення про потреби КРОЗ, оскільки не враховує регіональних особливостей захворюваності населення, тренди захворюваності, наявність обгрунтованої структури фінансування тощо. Тому, на наш погляд, описаний інструментарій закладає лише фундамент планування КРОЗ, але не дає змоги приступити до практичної реалізації. Для вирішення проблеми необхідні конкретизовані індикатори та орієнтири. Загальна схема, як приклад їх застосування, надана в таблиці 2.

юв'я: використання індикаторів та орієнтирів

Таблиця 2. Стан кадрових ресурсів охорони 3

\begin{tabular}{|c|c|c|c|c|c|}
\hline \multirow{2}{*}{$\begin{array}{l}\text { Характерис- } \\
\text { тика }\end{array}$} & \multirow[b]{2}{*}{ Індикатор } & \multirow{2}{*}{$\begin{array}{c}\text { Діапазон } \\
\text { регіональних } \\
\text { змін як } \\
\text { орієнтир }\end{array}$} & \multirow[b]{2}{*}{ Посилання } & \multicolumn{2}{|c|}{ Коментарі } \\
\hline & & & & індикатор / орієнтир (и) & джерело \\
\hline $\begin{array}{l}\text { Статус КРОЗ } \\
\text { - Рівень КРОЗ }\end{array}$ & $\begin{array}{l}\text { Кількість лікарів } \\
\text { на } 10000 \\
\text { населення }\end{array}$ & $1,0-2,0$ & $\begin{array}{l}\text { World Bank } \\
(1993)\end{array}$ & $\begin{array}{l}\text { Мінімальний пакет } \\
\text { втручань у клінічній } \\
\text { галузі та в галузі } \\
\text { суспільної охорони } \\
\text { здоров'я; стратегія } \\
\text { «Здоров'я для всіх» }\end{array}$ & $\begin{array}{l}\text { Доступні } \\
\text { міжнародні та } \\
\text { національні бази } \\
\text { даних / документи } \\
\text { МО3 }\end{array}$ \\
\hline $\begin{array}{l}\text { Статус КРОЗ } \\
\text { • Рівень КРОЗ }\end{array}$ & \begin{tabular}{|l|} 
Кількість \\
медсестер на \\
10000 населення
\end{tabular} & $2,0-4,0$ & $\begin{array}{l}\text { World Bank } \\
(1993)\end{array}$ & & $\begin{array}{l}\text { Доступні міжна- } \\
\text { родні та націо- } \\
\text { нальні бази даних } \\
\text { / документи МО3 }\end{array}$ \\
\hline $\begin{array}{l}\text { Статус КРОЗ } \\
\text { • Рівень КРОЗ }\end{array}$ & $\begin{array}{l}\text { Кількість КРОЗ } \\
\text { інших категорій } \\
\text { (наприклад, } \\
\text { стоматологів) на } \\
10000 \text { населення }\end{array}$ & $2,0-4,0$ & $\begin{array}{l}\text { Немає } \\
\text { міжнародних } \\
\text { орієнтирів }\end{array}$ & $\begin{array}{l}\text { Працівники первинної } \\
\text { ланки, лікарі-спеціалісти, } \\
\text { адміністратори та інший } \\
\text { допоміжний персонал }\end{array}$ & $\begin{array}{l}\text { Доступні } \\
\text { міжнародні та } \\
\text { національні бази } \\
\text { даних / документи } \\
\text { МО3 }\end{array}$ \\
\hline $\begin{array}{l}\text { Статус КРОЗ } \\
\cdot \\
\text { Рівномірність } \\
\text { розподілу } \\
\text { КРО3 }\end{array}$ & $\begin{array}{l}\text { Відношення най- } \\
\text { вищої щільності } \\
\text { лікарів, } \\
\text { медичних сестер } \\
\text { до найнижчої по } \\
\text { регіонах }\end{array}$ & $1,0-1,5$ & \begin{tabular}{|l|} 
На основі \\
принципу \\
справедливості
\end{tabular} & $\begin{array}{l}\text { Мінімальний пакет } \\
\text { втручань у клінічній } \\
\text { галузі та в галузі } \\
\text { суспільної охорони } \\
\text { здоров'я; стратегія } \\
\text { «Здоров'я для всіх» }\end{array}$ & $\begin{array}{l}\text { Доступні } \\
\text { міжнародні та } \\
\text { національні бази } \\
\text { даних / документи } \\
\text { МО3 }\end{array}$ \\
\hline $\begin{array}{l}\text { Статус КРОЗ } \\
\text { - Тендерний } \\
\text { розподіл } \\
\text { КРОЗ } \\
\end{array}$ & $\begin{array}{l}\text { Співвідношення } \\
\text { чоловіки: жінки, } \\
\text { за категоріями } \\
\text { КРОЗ } \\
\end{array}$ & Немає & $\begin{array}{l}\text { Немає } \\
\text { конкретного } \\
\text { джерела }\end{array}$ & $\begin{array}{l}\text { Категорії включають всі } \\
\text { спеціалізації }\end{array}$ & $\begin{array}{l}\text { Доступні міжна- } \\
\text { родні та націо- } \\
\text { нальні бази даних } \\
\text { / документи МО3 }\end{array}$ \\
\hline $\begin{array}{l}\text { Статус КРОЗ } \\
\text { • Діяльність } \\
\text { КРОЗ } \\
\text { (ефективність) }\end{array}$ & $\begin{array}{l}\text { Річний бюджет } \\
\text { на КРОЗ / } \\
\text { загальний річний } \\
\text { бюджет на } \\
\text { охорону здоров'я } \\
\end{array}$ & Немає & $\begin{array}{l}\text { Hornby \& Forte } \\
(2000)\end{array}$ & Немає & $\begin{array}{l}\text { Доступні } \\
\text { міжнародні та } \\
\text { національні бази } \\
\text { даних / документи } \\
\text { МО3 }\end{array}$ \\
\hline $\begin{array}{l}\text { Статус КРОЗ } \\
\text { • Діяльність } \\
\text { КРОЗ } \\
\text { (ефективність) }\end{array}$ & $\begin{array}{l}\text { Кількість КРОЗ } \\
\text { за категоріями / } \\
\text { річний бюджет } \\
\text { на КРОЗ певної } \\
\text { категорії } \\
\end{array}$ & Немає & $\begin{array}{l}\text { Немає } \\
\text { конкретного } \\
\text { джерела }\end{array}$ & Немає & $\begin{array}{l}\text { Доступні } \\
\text { міжнародні та } \\
\text { національні бази } \\
\text { даних / документи } \\
\text { МО3 }\end{array}$ \\
\hline $\begin{array}{l}\text { Статус КРО3 } \\
\text { - Діяльність } \\
\text { КРОЗ } \\
\text { (ефективність) } \\
\end{array}$ & \begin{tabular}{|l|} 
Загальні витрати \\
на КРОЗ на душу \\
населення
\end{tabular} & Немає & $\begin{array}{l}\text { Немає } \\
\text { конкретного } \\
\text { джерела }\end{array}$ & Немає & $\begin{array}{l}\text { Доступні міжна- } \\
\text { родні та націо- } \\
\text { нальні бази даних } \\
\text { / документи МО3 }\end{array}$ \\
\hline $\begin{array}{l}\text { Статус КРО3 } \\
\text { - Діяльність } \\
\text { КРОЗ } \\
\text { (ефективність) } \\
\end{array}$ & & Немає & $\begin{array}{l}\text { Hornby \& Forte } \\
(2000)\end{array}$ & Немає & $\begin{array}{l}\text { Доступні міжна- } \\
\text { родні та націо- } \\
\text { нальні бази даних } \\
\text { / документи МО3 }\end{array}$ \\
\hline
\end{tabular}


У таблиці 2 представлено лише деякі з широко використовуваних індикаторів. Природно, можливий розгляд конкретних категорій фахівців (включаючи менеджерів, адміністративний персонал тощо), якщо національні дані дозволяють це зробити, хоча загальних орієнтирів за цими категоріями немає та теоретично не може бути.

Середні рівні щільності можуть маскувати значні відмінності в розподілі людських ресурсів за географічною локалізацією, навиками, статтю тощо. Ці відмінності в розподілі можуть стати однією з найважливіших перешкод для досягнення спільних цілей щодо поліпшення стану здоров'я населення, задоволеності громадян та стійкого фінансового захисту. Географічний дисбаланс зазвичай означає зосередження медичних кадрів у містах а, отже, їх нестачу в сільських районах, що може мати принципове значення.

Крім основних індикаторів стану кадрових ресурсів охорони здоров'я - рівня щільності, розподілу загальних показників діяльності - існують проміжні причини змінення та стану рівня щільності, розподілу показників діяльності робочої сили, на які впливатимуть такі важелі, як фінансування, освіта й управління.
Тим не менш, обгрунтування невеликого набору індикаторів може бути корисним для оптимізації управління КРОЗ. Зрозуміло, що подібний набір складає лише частину управлінської інформації. Більше того, перелічені індикатори та орієнтири майже не враховують якість надання медичної допомоги. Тому розглянемо можливість планування КРОЗ із використанням цільових індикаторів ефективності їх роботи (табл. 3).

На практиці для розроблення політики, спрямованої на поліпшення структури КРОЗ, пропонується використання п'ятиетапної процедури [ 1-3]:

1. Оцінювання існуючих індикаторів стану кадрових ресурсів охорони здоров'я щодо орієнтирів у конкретний момент часу як у порівнянні з іншими країнами, так і між регіонами.

2. Оцінювання трендів існуючих індикаторів.

3. Розроблення критеріїв для визначення пріоритетних проблем кадрових ресурсів охорони здоров'я.

4. Вибір стратегії.

5. Обгрунтування та послідовність етапів стратегії, спрямованої на поліпшення стану кадрових ресурсів охорони здоров'я.

Таблиця 3. Кадрові ресурси охорони з юв'я: використання цільових індикаторів

\begin{tabular}{|c|c|c|c|c|c|}
\hline \multirow{2}{*}{ Характеристика } & \multirow{2}{*}{ Індикатор } & \multirow{2}{*}{ Орієнтир } & \multirow{2}{*}{ Посилання } & \multicolumn{2}{|c|}{ Коментарі } \\
\hline & & & & $\begin{array}{l}\text { індикатор / } \\
\text { орієнтир(и) }\end{array}$ & $\begin{array}{c}\text { джерело } \\
\text { для порівняння }\end{array}$ \\
\hline $\begin{array}{l}\text { Статус КРОЗ } \\
\text { • Діяльність } \\
\text { КРОЗ } \\
\text { (продуктивність) }\end{array}$ & $\begin{array}{l}\text { Середня тривалість } \\
\text { перебування в } \\
\text { стаціонарі }\end{array}$ & $\begin{array}{c}\text { Національні, } \\
\text { регіональні та } \\
\text { локальні } \\
\text { стандарти }\end{array}$ & $\begin{array}{l}\text { Немає } \\
\text { конкретного } \\
\text { джерела }\end{array}$ & $\begin{array}{l}\text { Міра здатності } \\
\text { персоналу до- } \\
\text { сягти цільових } \\
\text { показників } \\
\text { продуктивності }\end{array}$ & $\begin{array}{l}\text { Доступні } \\
\text { міжнародні та } \\
\text { національні бази } \\
\text { даних / } \\
\text { документи МО3 }\end{array}$ \\
\hline $\begin{array}{l}\text { Статус КРОЗ } \\
\text { • Діяльність } \\
\text { КРОЗ } \\
\text { (продуктивність } \\
\text { / якість) }\end{array}$ & $\begin{array}{l}\text { Число відвідувань для } \\
\text { отримання первинної } \\
\text { медико-санітарної } \\
\text { допомоги / загальна } \\
\text { чисельність персоналу }\end{array}$ & $\begin{array}{c}\text { Регіональні та } \\
\text { локальні } \\
\text { стандарти }\end{array}$ & $\begin{array}{l}\text { Hornby \& } \\
\text { Forte }(2000)\end{array}$ & $\begin{array}{l}\text { Міра здатності } \\
\text { персоналу до- } \\
\text { сягти цільових } \\
\text { показників } \\
\text { продуктивності }\end{array}$ & $\begin{array}{l}\text { Доступні } \\
\text { міжнародні та } \\
\text { національні бази } \\
\text { даних / } \\
\text { документи МО3 }\end{array}$ \\
\hline $\begin{array}{l}\text { Статус КРОЗ } \\
\text { - Діяльність } \\
\text { КРОЗ (якість } \\
\text { НМД) } \\
\end{array}$ & $\begin{array}{l}\text { Динаміка } \\
\text { захворюваності } \\
\text { населення }\end{array}$ & $\begin{array}{c}\text { Регіональні та } \\
\text { локальні } \\
\text { стандарти }\end{array}$ & $\begin{array}{l}\text { Немає } \\
\text { конкретного } \\
\text { джерела }\end{array}$ & Аналогічно & $\begin{array}{l}\text { Огляди докумен- } \\
\text { тів (наприклад, } \\
\text { систематичні } \\
\text { огляди) }\end{array}$ \\
\hline $\begin{array}{l}\text { Статус КРОЗ } \\
\text { • Діяльність } \\
\text { КРОЗ (якість } \\
\text { НМД) }\end{array}$ & $\begin{array}{l}\text { Кількість лікарських } \\
\text { помилок }\end{array}$ & Немає & $\begin{array}{l}\text { Немає } \\
\text { конкретного } \\
\text { джерела }\end{array}$ & Немає & Немає \\
\hline
\end{tabular}

Для оперативної корекції плану КРОЗ наданий інструментарій недостатній. Украй важливими є індикатори, що базуються на інформаційних технологіях та пов'язані з оцінюванням трендів. На жаль, дотепер вони не запропоновані.
Отже, з точки зору КРОЗ існує тільки дві можливі стратегії збільшення продуктивності системи охорони здоров'я - внаслідок збільшення кількості працюючих (екстенсивний шлях розвитку) і поліпшення умов роботи вже працюючих (інтенсифікація праці). 
Необхідно досягти компромісу, з одного боку, забезпечуючи меншу чисельність нових працівників охорони здоров'я або підвищуючи рівень підготовки наявних працівників, або поєднуючи обидва ці підходи i, 3 іншого боку, в масовому порядку збільшуючи чисельність нових працівників охорони здоров'я.

Стратегія збільшення кількості працівників охорони здоров'я може використовувати наявні та національні пріоритети, але вона ризикує стати занадто амбіційною для існуючих потужностей і нестійкою в довгостроковій перспективі, залишивши велике число медичних працівників без адекватної зарплати.

Стратегія зменшення кількості нових працівників охорони здоров'я менш небезпечна, оскільки, ймовірно, забезпечить більш високу якість навчання та буде стійкішою в довгостроковій перспективі.

Саме тому вважаємо, що в майбутньому буде корисною ступенева модель підготовки КРОЗ, оскільки вона може забезпечити при необхідності можливість прискореної підготовки фахівців необхідних спеціальностей. У іiі основу закладено градієнтно-переривчасто-ступеневий принцип підготовки фахівців у післядипломній медичній освіті.

Модель базується на трьох принципах - безперервна професійна освіта в інтернатурі та резидентурі 3 відносно невеликим часовим градієнтом (1-3 роки); поєднання державного регулювання й особистісних планів професійного розвитку; реалізація змішаної системи підготовки - проблемно-орієнтованої та особистісно-орієнтованої. Зрозуміло, що останній вид навчання здійснюється власним коштом.

Отже, пропонується така модель підготовки спеціалістів, при якій навчальний контент і функціональні обов'язки конгруентні. Термін навчання поділяється на період навчання в інтернатурі і період навчання в резидентурі, причому кожен випуск має можливість працювати відповідно до отриманих знань. Кожен період спеціалізації відповідає певним функціональним потребам системи охорони здоров'я. Після закінчення інтернатури (завершення першого рівня спеціалізації) більшість із випускників припиняє навчання до виникнення відповідних потреб. При зміні потреб у сторону підготовки вузьких спеціалістів частина слухачів, які закінчили попередній етап навчання, після складання відповідного іспиту, продовжує навчатися в резидентурі для заповнення вакансій. Як наслідок, забезпечується не тільки безперервний професійний розвиток лікарів, але й створення постійної мотивації для подальшого навчання. Зрозу- міло також, що при такому варіанті підготовки фахівців кадровий дисбаланс стає мінімальним.

Головною метою запропонованої авторами моделі має стати рейтингове значення етапів проходження курсів спеціалізації для роботодавця.

У наступному повідомленні автори нададуть результати розрахунків побудови системи градієнтнопереривчасто-ступеневого навчання для однієї зі спеціальностей.

Обговорення. Не існує простого способу аналізу ситуації в країні, встановлення пріоритетів, вибору рішень і розробки належної послідовності дій із інвестування з метою поліпшення кадрових ресурсів охорони здоров'я. Необхідно брати до уваги безліч чинників, включаючи доступність достовірних даних, технічну складову та здійсненність різних політичних настроїв, причому є достатній набір для визначення пріоритетів щодо проблемних областей, вибору технічно та політично здійсненних реформ і створення послідовного керівництва для аналізу нинішнього стану в порівнянні з орієнтирами («бенчмаркінг»).

Зрозуміло, що зміна навчальних програм або вимог до післядипломної підготовки (в інтернатурі та резидентурі) щодо підвищення якості, або зміна профілю працівників охорони здоров'я може викликати серйозне протистояння з боку залучених навчальних закладів і підрозділів, таких як професорсько-викладацький склад вищих медичних навчальних закладів, але може активно підтримуватися технічними працівниками організацій-донорів і керівним персоналом MO3.

Висновки. 1. Пропонується градієнто-переривчасто-ступенева система підготовки фахівців при післядипломній медичній освіті, що наповнює змістом навчання та створює постійну мотивацію до подальшого навчання. Подібна система підготовки фахівців забезпечує умови для мінімізації кадрового дисбалансу.

2. Рекомендується для обчислення потреби в КРО3 користуватися цільовими індикаторами та орієнтирами, такими як динаміка захворюваності на найважливіші хвороби, демографічна структура населення і його територіальний розподіл, регіональні та державні показники якості та ефективності медичної допомоги, функції і співвідношення лікарського і сестринського персоналу, доцільні нормативи навантаження медпрацівників тощо. 


\section{Література}

1. Руководство по мониторингу и оценке кадровых ресурсов здравоохранения. Адаптировано для применения в странах с низким и средним уровнем доходов I под ред. Mario R. Dal Poz Neeru Gupta Estelle Quain, Agnes L.B. Soucat. Женева : Всемирная организация здравоохранения, $2 \mathrm{O} 2$. -216 c.

2. Оценка финансирования, образования, управления и политического контекста для стратегического планирования кадровых ресурсов здравоохранения I под ред. Ibomas Bosserti, Till Barnighausen, Diana Bowser, Andrew Mitchell,
Gulin Gedik. - Женева : Всемирная организация здравоохранения, 2009. - 91 с.

3. Оценка будущих потребностей в кадрових ресурсах здравоохранения / под ред. Gilles Dussault, James Buchan, Walter Sermeus, Zilvinas Padaiga. -Бельгия : Европейская обсерватория по системам и политике здравоохранения, 2010. $45 \mathrm{c}$.

4. Модели и инструменты планирования и прогнозирования в кадровых ресурсах здравоохранения. - Женева : Всемирная организация здравоохранения, 2010. - 32 с. 